Fikrah: Jurnal Ilmu Aqidah dan Studi Keagamaan

ISSN 2354-6147 EISSN 2476-9649

Tersedia online di: journal.stainkudus.ac.id/index.php/fikrah

DOI: 10.21043/fikrah.v6i1.3412

\title{
Media sosial dan Perilaku Keberagamaan Santri Remaja di Pondok Pesantren Nurul Huda Kajen
}

\author{
Nurul Laily \\ Institut Agama Islam Negeri Kudus, Indonesia \\ nurul22laily@gmail.com
}

\begin{abstract}
Abstrak
Artikel ini membahas tentang hubungan media sosial dan perilaku kebergamaan santri di Pesantren Nurul Huda Kajen. Santri di pesantren tersebut bisa mengakses media sosial sebagai wadah untuk mengenal dunia, tetapi yang menjadi masalah ialah bagaimana para santri memanfaatkan dan meggunakan media sosial apakah sudah sesuai atau tida. Artikel ini bertujuan untuk mendeskripsikan kegunaan dan perilaku santri di Pondok Pesantren Nurul Huda Kajen kecamatan Margoyoso kabupaten Pati. Artikel ini termasuk jenis artikel field Research dengan teknik pendekatan kualitatif. Teknik pengumpulan data meliputi wawancara, observasi dan dokumentasi. Hasil artikel menunjukkan dua model perilaku santri setelah mengenal media sosial positif dan negatif. Adapun positif yaitu menggali informasi yang membantu pelajara dan negatif ialah hilang tanggungjawab santri atas perilaku yang telah dilakukan. Solusinya ialah santri harus dibekali pemahaman agama yang komprehensif agar tetap menjaga nilainilai agama ketika menggunakan media sosial, dan jauh dari perilaku kriminal.
\end{abstract}

Kata kunci: media sosial, keberagamaan santri, pesantren Nurul Huda. 


\begin{abstract}
This article discusses the relationship between social media and the religious behavior of students in the Nurul Huda Kajen Islamic Boarding School. Santri in the pesantren can access social media as a place to get to know the world, but the problem is how the students use and use social media whether it is appropriate or not. This article aims to describe the usefulness and behavior of students in the Nurul Huda Kajen Islamic Boarding School in Margoyoso district, Pati regency. This article includes the field research article type with qualitative approach techniques. Data collection techniques include interviews, observation and documentation. The results of the article show two behavioral models of santri after getting to know positive and negative social media. The positive is to dig up information that helps learning and negativity is the loss of santri responsibility for the behavior that has been done. The solution is for santri to be equipped with a comprehensive understanding of religion in order to maintain religious values when using social media, and away from criminal behavior.
\end{abstract}

Keywords: Social media, santri religiousities, Pesantren Nurul Huda.

\title{
Pendahuluan
}

Zaman modern memberikan kemudahan bagi santri untuk mengakses media sosial tanpa mempertimbangkan dampak positif dan negatifnya. Sikap remaja yang labil menegaskan tentang rentannya gejolak pada dirinya dengan kepribadian yang cepat berubah-ubah, sehingga banyak remaja yang mencari alternatif hiburan yang berbasis teknologi, salah satunya adalah media sosial. Media ini dapat dianggap kehidupan baru, selain dunia nyata yang ada di hadapanya. Pada masa remaja agama belum menjadi identitas bagi santri. Krisis identitas dalam dimensi agama menjadi salah satu penyebab dari kemerosotan moral remaja, sehingga mereka mudah terpengaruh oleh lingkungan sosial yang membawa mereka kepada perbuatan kurang baik.

Kekosongan rohaniyah dalam diri remaja memberikan peluang munculnya berbagai problematika, baik bersifat personal maupun sosial. Keyakinan agama dalam hal ini melalui pendidikan agama yang terbentuk pada diri remaja dapat dijadikan tolak ukur sejauh mana remaja memiliki sense ofresponsibility (rasa tanggung jawab) sehingga mereka mampu menghindari hal negatif dari luar. Pada wilayah ini, pendidikan agama Islam menjadi pondasi bagi setiap manusia, karena dengan belajar agama manusia dapat mengupayakan dirinya untuk selalu berbuat baik. Hal ini disebabkan nilai-nilai agama yang mengajarkan tentang kebaikan dan keshalehan. Oleh sebab itu, agama diyakini dapat membentengi diri dari segala hal yang bersifat buruk. Meskipun 
berkaitan dengan modernisasi yang mempermudah orang berinterkasi melalui praktik globalisasi yang disebabkan oleh kemajuan teknologi.

Pentingnya aspek rohani dalam kehidupan manusia memberikan dampak positif dalam berperilaku dan problem sosial, seperti yang diungkapkan Zakiah Darajat (1970, hal. 35) bahwa semakin jauh seseorang dari agama akan semakin sulit untuk mencari ketentraman batin. Namun orientasi pendidikan yang berbasis teknologi informasi tanpa adanya pendampingan pendidikan agama Islam membuat remaja mengesampingkan sikap beragama dan akan menimbulkan sikap tidak terpuji yang ditampilkan bagian dari Pendidikan berbasis teknologi diantaranya media sosial (Saputra, 2016, hal. 161) . Menurut Utari (2011, hal. 51) media sosial adalah sebuah media online dimana para penggunanya dapat dengan mudah berpartisipasi dalam berbagi informasi, menciptakan konten atau isi yang ingin disampaikan kepada orang lain, memberi komentar terhadap masukan yang diterimanya dan seterusnya. Setidaknya terdapat beberapa media sosial yang beragam fungsi dan tujuan masinmasing. Facebook, twitter, path, whatsapp, instagram, line, Blackberry Massagger (BBM), dan lain sebagainya. Membanjirnya aplikasi media sosial ini tak bisa lepas dari kebutuhan pasar yang cenderung menginginkan hal-hal kekinian yang semakin canggih, mudah diakses, dan memiliki kelebihan dari yang lain.

Realitas atas perkembangan teknologi juga menyebar di dunia pesantren, seperti pondok pesantren Nurul Huda Kajen yang banyak memberikan fasilitas seperti komputer juga wifi yang digunakan untuk mencari beberapa informasi yang bersangkutan dalam tugas sekolah. Realita tidak hanya berdampak pada pembelajaran, tetapi juga berdampak pada perilaku para santri dan remaja karena media memberikan ruang yang luas bagi penggunanya. Pada dasarnya, pesantren telah memberikan ruang bagi santri untuk belajar berbagai disiplin ilmu sebagai bekal di masyarakat.

Artikel yang betemakan pesantren dan media telah banyak ditulis, seperti Eddy Saputra (2016) yang berjudul "Dampak Media Sosial terhadap Sikap Keberagamaan Remaja dan Solusinya melalui Pendidikan Agama Islam". Adapun simpulannya ialah bahwa media sosial dapat menjadi alat komunikasi yang pada satu wilayah harus diperhatikan, karen media tidak mempunyai filter dalam penyebarannya kecuali orang 
yang menggunakan. Pada wilayah ini pendidikan agama menjadi alat yang dapat menyaring penyebaran dampak negatif dari media sosial. Sedangkan dalam artikel Wahyu Nugroho (2016) yang berjudul "Peran Pondok pesantren dalam pembinaan keberagamaan remaja" memberikan simpulan bahwa ekonomi keluarga dapat mempengaruhi remaja, sehingga pesantren dianggap sebagai tempat yang dapat memberikan bekal kehidupan yang lebih baik di masa yang akan datang.

Artikel ini lebih membahas pada aspek relasi keterpengaruhan yang terdapat di media bagi remaja di pondok pesantren di Pati. Dengan anggapan sederhana bahwa media sosial dapat memberikan dampak positif bagi santri dalam menuntut ilmu. Berkat media, santri dapat terbantu dalam menyelesaikan masalah keilmuan dan dapat mengenal problem yang lebih luas, sehingga santri dapat mengenal kehidupan sosial dari media dan kehidupan keagamaan dari pesantren, dengan harapan hidupnya kelak menjadi orang yang bermanfaat di dunia maupun di akhirat.

\section{Metode Penelitian}

Artikel ini adalah kajian lapangan (field research) dan menggunakan pendekatan kualitatif (Azwar, 2010). Observasi dan wawancara dilaksanakan di Pondok Pesantren Nurul Huda Kajen. Informan dalam artikel ini adalah santri, kyai, ustad, tokoh agama dan masyarakat sekitar. Adapun teknik pengumpulan data yang digunakan dalam artikel ini adalah observasi, interview, dan dokumentasi.

\section{Media Sosial dan Perilaku Keagamaan}

Thorton menyatakan bahwa gagasan tentang budaya autentik yang terbentuk di luar media adalah sesuatu yang fleksibel, namun salah arah karena perbedaan subkultur pemuda. Dalam banyak kasus adalah fenomena media. Media katanya adalah bagian integral dari pembentukan subkultur dan bagian formulasi anak-anak muda atas aktivitas mereka (Barker, 2005, hal. 353). Media massa biasanya dianggap sebagai sumber berita dan hiburan. Media massa juga membawa pesan persuasi kepada setiap orang yang menggunakannya. (Holmes, 2012, hal. 87). Media massa telah merasuk ke dalam kehidupan modern. Setiap bangun pagi masyarakat mendengarkan radio, memainkan gadget yang terhubung dalam jaringan internet, dan menonton televisi 
karena media massa sangat sangat berpengaruh, kita perlu tahu sebanyak mungkin bagaimana media massa bekerja. Pertama, melalui media massa kita mengetahui hampir segala sesuatu yang kita tahu tentang dunia di luar lingkungan kita. Apa yang anda ketahui tentang Baghdad dan badai Katrina jika tidak ada internet, televisi dan lain sebagainya. Kedua, masyarakat yang berpengetahuan (informed) dan aktif sangat mungkin tewujud di dalam demokrasi modern hanya jika media massa berjalan dengan baik. Ketiga, orang membutuhkan media massa untuk mengekspresikan ide-ide mereka ke khalayak luas. Tanpa media massa, gagasan mereka hanya akan sampai ke sekitar orang-orang anda dan orang-orang yang anda kirimi surat dak keempat Negara-negara kuat menggunakan media massa untuk menyebarkan ideologinya dan untuk tujuan komersial. Media massa adalah alat utama para propagandis, pengiklanan, dan pada orang-orang semacam itu (Vivian, 2008, hal. 5).

Sarjana komunikasi awal mengasumsikan bahwa media massa sangat kuat sehingga ide-ide dan bahkan instruksi pemungutan suara sekalipun dapat disuntikan ke dalam lembaga politik. Keraguan muncul pada tahun 1940-an tentang apakah media benar-benar punya kekuatan demikian hebat, dan para sarjana mulai melakukan riset berdasarkan asumsi bahwa pengaruh media paling banter hanya bersifat moderat. Studi yang baru mengkaji tentang efek komulatif jangka panjang dari media (Rivers, 2012, hal. 79). Bagi sebagian orang, gagasan bahwa media massa biasanya tidak mempunyai dampak apapun terhadap para penikmatnya, justru tidak tampak sangat beralasan. Para peneliti juga mulai mempertimbangkan kemungkinan, bahwa mereka mungkin mencari dampak di tempat yang salah. Selama bertahun-tahun, pendekatan yang digunakan dalam riset komunikasi adalah mencari perubahan sikap dan sebagaian besar riset menemukan, bahwa media massa mempunyai dampak kecil dalam bidang ini, tetapi mungkin para peneliti melihat sasaran yang salah. Mungkin media massa berdampak pada persepsi orang atau pandangan mereka terhadap dunia daripada mereka sendiri (Severin \& Tankard, 2011, hal. 265).

Berbeda dengan apa yang ditulis oleh Chris Barker dalam bukunya Cultural Studies yang mengatakan bahwa media massa memainkan peran yang sangat penting. Melalui konsep "kepanikan moral" dan "perluasan menyimpang", para penulis semacam Cohen dan Young menempatkan liputan media massa pada posisi sentral 
dalam penciptaan dan keberlangsungan penyimpangan subkultur pemuda. Media dikatakan terikat dalam sekelompok anak muda tertentu dan memberi label prilaku mereka dengan sebutan menyimpang, menganggu, dan kelihatannya akan terus berulang perilaku mereka sebagai iblis rakyat kontemporer (Barker, 2005, hal. 352). Fenomena demikian menandakan bahwa media mempunyai peran dan pengaruh yang sangat signifikan bagi individu atau kelompok tertentu. Gagasan bahwa pemerintah adalah pusat struktur kehidupan manusia kini mulai mengalami perubahan. Dengan media massa mengambil alih peran utama itu. Di seluruh dunia kekuasaan yang pernah dipegang pemerintah untuk mengontrol komunikasi massa kini telah jauh melemah.

\section{Media sosial}

Media sosial merupakan salah satu fenomena yang muncul seiring berkembangnya teknologi dan inovasi di internet. Selain sebagai media baru dalam berinteraksi dan bersosialisasi, media sosial juga memiliki pengaruh yang luar biasa terhadap berbagai aspek, seperti jurnalisme, public relations, dan pemasaran (Nasrullah, 2015, hal. 1). Media sosial mengajak siapa saja yang tertarik untuk berpartisipasi dengan memberi feedback secara terbuka memberikan komentar, serta membagi informasi dalam waktu yang cepat dan tak terbatas. Tidak dapat dipungkiri bahwa media sosial mempunyai pengaruh yang besar dalam kehidupan. Seseorang yang awal mulanya tidak mengetahui tentang adanya media sosial, sesuai dengan perubahan perkembangan di era modern, mereka akhirnya mengetahui apa itu media sosial? bagaimana cara penggunaannya dalam kehidupan? apa manfaat yang di dapat dalam penggunaan media sosial?. Bagi masyarakat khususnya kalangan remaja, media sosial sudah menjadi candu yang membuat penggunanya tiada hari tanpa membuka media sosial.

Media sosial pada dasarnya media sosial merupakan perkembangan mutakhir dari teknologi-teknologi web baru berbasis internet, yang memudahkan semua orang untuk dapat berkomunikasi, berpartisipasi, saling berbagi dan membentuk sebuah jaringan secara online, sehingga dapat menyebarluaskan konten mereka sendiri. Post di blog, Tweet, atau video You tube dapat diproduksi dan dapat dilihat secara langsung oleh jutaan orang secara gratis. Media mempunyai banyak bentuk diantaranya yang paling populer yaitu microblogging (twitter), facebook, dan blog. Twitter adalah suatu 
situs web yang merupakan layanan dari microblog, yaitu suatu bentuk blog yang membatasi ukuran setiap post-nya, yang memberikan fasilitas bagi pengguna untuk dapat menuliskan pesan twitter update hanya berisi 140 karakter. Twitter merupakan salah satu jejaring sosial yang paling mudah digunakan, karena hanya memerlukan waktu yang singkat tetapi informasi yang disampaikan dapat langsung menyebar secara luas (Nasrullah, 2015, hal. 10).

Media sosial adalah sebuah media online, dengan para penggunanya bisa dengan mudah berpartisipasi, berbagi, dan menciptakan isi meliputi blog, jejaring sosial, wiki, forum dan dunia virtual. Blog, jejaring sosial dan wiki merupakan bentuk media sosial yang paling umum digunakan oleh masyarakat di seluruh dunia (Nasrullah, 2015, hal. 5). Manusia biasa yang saling membagi ide, bekerjasama, dan berkolaborasi untuk menciptakan kreasi, berfikir, berdebat, menemukan orang yang bisa menjadi teman baik, menemukan pasangan, dan membangun sebuah komunikasi. Sementara jejaring sosial merupakan situs dimana setiap orang bisa membuat web page pribadi, kemudian terhubung dengan teman-teman untuk berbagi infomasi dan berkomunikasi. Jejaring sosial terbatas antara lain fecebook, Whats App, Myspace, Twitter,You Tube, dan Instagram.

Media sosial memberikan ruang kebebasan berkomentar serta menyalurkan 2 pendapatnya tanpa rasa khawatir. Hal ini dikarenakan dalam internet khususnya media sosial sangat mudah memalsukan jati diri atau melakukan kejahatan. Padahal dalam perkembangannya di sekolah, remaja berusaha mencari identitasnya dengan bergaul bersama teman sebayanya. Namun saat ini sering kali remaja beranggapan bahwa semakin aktif dirinya di media sosial maka mereka akan semakin dianggap gaul. Sedangkan remaja yang tidak mempunyai media sosial biasanya dianggap kuno atau ketinggalan zaman dan kurang bergaul. Masa remaja merupakan masa yang menunjukan dengan jelas sifat transisi atau peralihan, karena masa remaja belum memperoleh status dewasa dan tidak lagi memiliki status anak-anak. Masa remaja merupakan masa transisi sebab pada saat itu seseorang telah meninggalkan masa kanakkanak namun ia juga belum memasuki masa dewasa. Disamping masatransisi remaja juga memiliki perubaham yang mencakup kematangan mental, emosional, sosial dan fisik (Atkinson, n.d., hal. 135). 
Kalangan remaja yang menjadi hiperaktif di media sosial ini juga sering memposting kegiatan sehari-hari mereka yang seakan menggambarkan gaya hidup mereka yang mencoba mengikuti perkembangan zaman. Namun apa yang mereka posting di media sosial tidak selalu menggambarkan keadaan perilaku sosial mereka yang sebenarnya (Jauhari, 2006). Ketika para remaja tersebut memposting sisi hidupnya yang penuh kesenangan, tidak jarang kenyataannya dalam kehidupan mereka merasa kesepian. Manusia sebagai aktor yang kreatif mampu menciptakan berbagai hal, salah satunya adalah ruang interaksi dunia maya. Setiap individu mampu menampilkan karakter diri yang berbeda ketika berada di dunia maya. Padahal dalam perkembangannya di sekolah, remaja berusaha mencari identitasnya dengan bergaul bersama teman sebayanya.

Adapun akhlak juga sangat memiliki peranan yang amat besar sekali karena akhlak seseorang pada umumnya merupakan buah dari pola fikirnya, orang mu'min yang paling sempurna imannya adalah yang paling baik akhlaknya, jika aqidahnya benar, maka baik pula akhlaknya. Adapun di masa sekarang akhlak remaja banyak yang sudah terpengaruh dengan media sosial yang mana media sosial meracuni pikiran para remaja. Dapat di ketahui, bahwa akhlak manusia pada zaman sekarang banyak yang bertentangan dengan agama, contohnya: pada saat azan berkumandang di masjid, banyak orang tidak mengindahkan kumandang azan dan lebih mementingkan dengan kegiatannya masing-masing, terlebih lagi para remaja yang mana mereka masih dalam masa peralihan untuk dapat mengetahui mana yang baik dan buruk dalam bersikap maupun dalam hal lainnya.

\section{Perilaku Keagamaan Remaja}

Sebelum membahas tentang perilaku keagamaan, terlebih dahulu penulis membahas apa itu yang dinamakan perilaku. Perilaku adalah sifat seseorang yang tercermin dalam kehidupan sehari-hari yang mana sifat tersebut tumbuh dan berkembang di dalam kehidupan masyarakat (Kebudayaan, 1989, hal. 659). Sedangkan keagamaan berasal dari kata agama yang berarti suatu sistem, prinsip, kepercayaan kepada Tuhan dengan ajaran kebaktian dan kewajiban-kewajiban yang berhubungan dengan kepercayaan itu (Nasional, 2008, hal. 10). Istilah keagamaan sendiri dapat 
diartikan sebagai sifat-sifat yang terdapat dalam agama atau segala sesuatu mengenai agama.

Sedangkan menurut beberapa ahli, menurut Departemen pendidikan dan kebudayaan, " Kamus Besar Bahasa Indonesia”. Perilaku adalah tanggapan reaksi individu yang terwujud dalam gerakan (sikap) tidak saja badan dan ucapan (Nasional, 2008, hal. 13). Sedangkan menurut Ahmad Amin dalam buku "etika". Perilaku keagamaan merupakan setiap perbuatan yang didasarkan kehendak disebut "kelakuan", seperti kata benar atau dusta, perbuatan dermawan atau kikir (Amin, 1983, hal. 12).

Agama yang dimaksud dalam pembahasan jurnal ini adalah agama Islam, maka secara sederhana pengertian bahwa perilaku keagamaan merupakan seluruh aktifitas anggota tubuh manusia yang berdasarkan syariat Islam atau ibadah dalam arti luas. Dengan kata lain perilaku keagamaan merupakan serangkaian tingkah laku seseorang yang dilandasi oleh ajaran-ajaran agama islam, baik berbentuk deviasi vertikal maupun yang berbentuk deviasi horizontal. Hal ini sesuai dengan pendapat Drs. H.M. Hafi Anshori bahwa, "kelakuan religious menurut sepanjang ajaran agama berkisar dari perbuatan-perbuatan ibadah, atau amal shaleh dan akhlak, baik secara vertikal terhadap tuhan, ataupun secara horizontal sesama makhluk" (Ansyori, 1999, hal. 48).

Perilaku keagamaan merupakan tindakan, cara berbuat atau perbuatan dari seseorang yang kesehariannya tidak lepas dari aktivitas yang berhubungan dengan agama yang diyakininya agar tidak terjadi kekacauan di dalam kehidupan sehari-hari. Berbicara mengenai agama dan perilaku di dalamnya, maka akan ditemukan bahwa agama mempunyai ajaran-ajaran tentang norma-norma akhlak yang tinggi, kebersihan jiwa, tidak mementingkan diri sendiri dan sebagainya. Itulah norma-norma yang diajarkan agama-agama karena tanpa adanya ajaran, norma-norma tidak akan berarti karena nantinya manusia akan bertindak sesuka hatinya atau spontan dan mudah tanpa dibuat-buat dan tanpa pemikiran (baik buruknya tingkah laku manusia).

Menurut Djamaludin Ancok dan Fuad Anshori Suroso bahwa perilaku keagamaan bukan hanya terjadi ketika seseorang melakukan perilaku ritual (beribadah), tapi juga ketika melakukan aktivitas lain yang didorong oleh kekuatan supranatural. Bukan hanya yang berkaitan dengan aktivitas yang tampak dan dapat dilihat mata, tapi 
juga aktivitas yang tidak tampak dan terjadi dalam hati seseorang, seperti dzikir dan doa dan lain sebagainya (Suroso, 2004, hal. 77).

Perilaku keagamaan terbentuk dan dipengaruhi oleh dua faktor, dimana kedua faktor ini bisa menciptakan kepribadian dan perilaku keagamaan seseorang. Kedua faktor tersebut yaitu faktor intern dan faktor ekstern. Faktor intern ini menyatakan bahwa manusia adalah homo religious (makhluk beragama), karena manusia sudah memiliki potensi untuk beragama, dimana tiap-tiap manusia yang lahir ke muka bumi membawa suatu tabiat dalam jiwanya, tabiat ingin beragama yaitu ingin mengabdi dan menyembah kepada sesuatu yang dianggapnya maha kuasa. Pembawaan ingin beragama ini memang telah menjadi fitrah kejadian manusia yang diciptakan oleh Yang Maha Kuasa dalam diri manusia (Hakim, 1979, hal. 11).

Sedangkan faktor ekstren yaitu segala sesuatu yang ada diluar pribadi dan mempunyai pengaruh pada perkembangan kepribadian dan keagamaan seseorang seperti keluarga, teman sepergaulan, dan lingkungan sehari-hari yang sering banyak persinggungan. Jadi, selain dari pada insting dan pembawaan jiwa ada lagi hal yang mendorong manusia untuk beragama yaitu suasana kehidupan di muka bumi ini. Urian ini menunjukkan, bahwa perilaku keagamaan pada dasarnya bukan hanya terjadi ketika seseorang melakukan perilaku ritual (beribadah) saja, tetapi juga ketika melakukan aktivitas lain yang didorong oleh kekuatan lahir. Oleh karena itu, keberagaman seseorang akan meliputi berbagai macam sisi atau dimensi.

Menurut Glock Stark seperti yang dikutip Ancok dan Suroso ada lima macam dimensi keberagaman yaitu dimensi keyakinan (ideologis), dimensi peribadatan atau praktek agama (ritualistic), dimensipenghayatan (experiensial), dimensi pengalaman (konsekuensial), dimensi pengetahuan agama (intelektual) (Hakim, 1979, hal. 77). Oleh karena itu, perilaku keagamann merupakan satu kesatuan perbuatan manusia yang mencakup tingkah laku dan aktivitas manusia. Pertama, dimensi keyakinan. Dimensi ini berisi pengaharapan di mana orang religius berpegang teguh pada pandangan teologis tertentu dan mengakui kebenaran doktrin-doktrin tersebut. jadi keyakinan itu berpangkal di dalam hati. Dengan adanya tuhan yang wajib disembah yang selanjutnya keyakinan akan berpengaruh ke dalam segala aktivitas yang dilakukan oleh seorang 
manusia sehingga aktivitas tersebut bernilai ibadah. Setiap agama mempertahankan seperangkat kepercayan dimana para penganut nya diharapkan taat (Suroso, 2004, hal. 77). Kedua, dimensi praktek agama. Dimensi ini mencakup perilaku pemujaan, ketaatan dan hal-hal yang dilakukan untuk menunjukkan komitmen terhadap agama yang dianutnya.

Praktek-praktek keagamaan ini terdiri atas dua kelas (Roberston, 1993, hal. 295), yaitu: (a) Ritual, mengacu kepada seperangkat ritus. Tindakan keagamaan formal dan praktek-praktek suci yang semua mengharapkan pemeluk melaksanakannya. Sebagai contoh dalam menampakkan ritual yaitu dalam agama Islam yang diwujudkan dalam ibadah shalat setiap hari, pengajian, perkawinan dan lain sebagainya. (b) Ketaatan merupakan tindakan persembahan dan kontemplasi personal yang relative spontan informal dan khas pribadi. Jadi ketaatan adalah wujud dari suatu keyakinan, sebagai contoh di kalangan penganut agama Islam yang melaksanakan shalat, puasa atau haji (Hakim, 1979, hal. 147).

Ketiga, dimensi pengalaman. Dimensi ini berisikan dan memperhatikan fakta bahwa semua agama mengandung pengaharapan-pengharapan tertentu. Jadi dalam dimensi ini agama merupakan suatu pengalaman yang awalnya tidak dirasa menjadi hal yang dapat dirasakan. Misalnya orang yang terkena musibah pasti orang tersebut akan membutuhkan suatu ketenangan sehingga kembali kepada Tuhan. Keempat, dimensi pengetahuan agama. Dimensi ini mengacu kepada harapan bahwa orang-orang yang beragama paling tidak memiliki sejumlah minimal pengetahuan mengenai dasar-dasar keyakinan, ritus-ritus, kitab suci tradisi-tradisi. Orang yang pengetahuan agamanya luas, mendalam. Maka orang tersebut akan semakin taat dan khusus dalam beribadah dibandingkan dengan yang tidak mengetahui agama. Contohnya orang yang memuja tuhannya akan mendapatkan pahala, sehingga mereka selalu mendekat dengan tuhannya. Kelima, dimensi pengalaman atau konsekuensi komitmen. Dimensi ini mengacu pada identifikasi akibat keyakinan keagamaan, praktek, pengalaman, dan pengetahuan seorang dari hari ke hari. Jadi dalam dimensi pengalaman atau konsekuensi komitmen ini adanya praktek-praktek pengalaman diwujudkan dengan keyakinan agamanya, baik yang berhubungan khusus maupun umum (Suroso, 2004, hal. 78). 
Adapun pembagian konsep lima dimensi di atas mempunyai kesesuaian dengan bentuk agama. Dalam satu aliran kepercayaan dimensi keyakinan atau kepercayaan disebut dengan akidah sedangkan dimensi praktek agama pemujaan atau penyembahan disebut dengan ibadah dan dimensi peraturan-peraturan dalam melaksanakan hubungan terhadap Tuhan dan sesama manusia dengan syariat. (Agus Hakim. 1996. hlm 15). Dengan demikian, dimensi isoterik dari suatu agama atau kepercayaan pada dasarnya tidak berdiri sendiri, tetapi berkaitan dengan dimensi luar dirinya. Selain dibentuk oleh substansi ajarannya, dimensi ini juga dipengaruhi oleh struktur sosial dimana suatu keyakinan itu dimanivestasikan oleh para pemeluknya. Sehingga dalam konteks tertentu, disatu sisi, agama juga dapat beradaptasi dan pada sisi yang berbeda dapat berfungsi sebagai alat legitimasi dari proses perubahan yang terjadi disekitar kehidupan para pemeluknya.

\section{Faktor-Faktor yang Mempengaruhi Perilaku Keagamaan}

Perilaku keagamaan terbentuk dan dipengaruhi oleh dua faktor, dimana kedua faktor ini bisa menciptakan kepribadian dan perilaku keagamaan seseorang. Kedua faktor tersebut adalah faktor intern dan faktor ekstren.

Adapun faktor Intern ialah merupakan pengaruh emosi (perasaan) yang mana dari pengaruh emosi (perasaan) tersebut akan memunculkan selektifitas. Selektifitas disini merupakan adanya pilih atau minat perhatian untuk menerima dan mengolah pengaruh-pengaruh yang datang dari luar diri manusia (Drajat, 1970, hal. 77). Emosi mempunyai pengaruh yang cukup besar dalam pembentukan perilaku keagamaan. Hal ini didukung oleh Dr. Zakiyah Darajat yang menyatakan : "sesungguhnya emosi memegang peranan penting dalam sikap dan tindak agama seseorang yang dapat dipahami tanpa menghindari emosinya, lebih ditegaskan lagi bahwa sesungguhnya pengaruh perasaan (emosi) jauh lebih besar dari pada rasio (logika)." (Drajat, 1970, hal. $80)$.

Sedangkan faktor ekstren yaitu segala sesuatu yang ada diluar pribadi dan mempunyai pengaruh pada perkembangan kepribadian dan juga keagamaan seseorang. Faktor ekstren diantaranya meliputi: Pertama, lingkungan Keluarga,Pengaruh keluarga besar sekali terhadap tingkah laku anggotanya karena lingkungan merupakan 
pendidikan utama dan pertama bagi anggotanya. Situasi pendidikan dalam keluarga akan terwujud dengan baik berkat adanya pergaulan dan hubungan saling mempengaruhi cara timbal balik antara orang tua dan anak. Suasana keluarga yang terbiasa melakukan perbuatan-perbuatan terpuji dan meninggalkan yang tercela akan menyebabkan anggotanya tumbuh dengan wajar dan akan tercipta keserasian dalam keluarga. Sehingga pengaruh keluarga akan membekas sekali bukan hanya dalam pribadi keluarganya tetapi juga dalam sikap perilaku keagamaan anggotanya.

Kedua, lingkungan masyarakat, masyarakat Indonesia bisa dibilang sebagai masyarakat yang berjiwa masyarakat sosialitas-relegious, sikap pribadinya berkembang dalam ruang lingkup (pola) sosialitas-relegious. Dimana garis hidup yang menghubungkan khaliknya (garis vertikal) merupakan kerangka dasar sikap dan pandangan yang selalu berkembang secara harmonis. Dan untuk memperoleh kerangka dasar sikap dan pandangan, manusia mengalami perkembangan yang berada dalam proses belajar secara individual dan belajar secara sosial. Antara individual "learning" dan "sosial learning" terjadi suatu perpaduan dalam rangka pembentukan pribadi manusia sebagai anggota masyarakat atau kelompok (H.M, 1997, hal. 127). Jadi jelas lingkungan masyarakat tidak kalah pentingnya dalam pembentukan pribadi manusia karena dalam masyarakat berkembang berbagai lembaga atau organisasi, baik lembaga ekonomi, sosial, budaya dan juga lembaga agama yang mempengaruhi arah perkembangan hidup, khususnya menyangkut sikap dan tingkah laku.

Ketiga, media komunikasi yang membawa misi agama. Satu faktor yang mempengaruhi perubahan perilaku seseorang adalah interaksi di luar kelompok. Yang dimaksud interaksi di luar kelompok adalah interaksi dengan buah kebudayaan manusia yang sampai kepadanya melalui alat-alat komunikasi seperti surat kabar, radio, televisi, buku dan lain sebagainya (W.A, 1991, hal. 155). Apabila yang disampaikan melalui alat komunikasi tersebut adalah hal-hal yang berkenaan dengan agama, maka secara otomatis perubahan perilaku yang muncul adalah perubahan perilaku keagamaan.

Keempat, kewibawaan seseorang yang mengemukakan sikap atau perilaku. Dalam hal ini adalah yang berotoritas dan berprestasi tinggi dalam masyarakat yaitu 
para pemimpin baik formil maupun non formil (pejabat atau ulama). Dari kewibawaan mereka akan memunculkan simpati, sugesti dan imitasi pada seseorang atau masyarakat. Oleh karena itu dakwah atau penerangan agama yang disampaikan oleh orang-orang yang memiliki otoritas dan prestise dalam bidangnya akan diterima masyarakat dengan cepat dan penuh keyakinan (H.M, 1997, hal. 126). Kelima, lingkungan sekolah atau kampus, Sekolah atau kampus merupakan suatu lembaga resmi yang di dalamnya terdapat pendidikan formal dengan program yang sistematik dengan melaksanakan bimbingan pengajaran dan latihan kepada muridnya, agar mereka bisa berkembang dengan optimal sesuai dengan potensi mereka, secara keseluruhan baik menyangkut tentang psikis (intelektual dan emosional), fisik, sosial maupun moral spiritual.

\section{Bentuk-Bentuk Perilaku Keagamaan}

Berdasarkan pengertian perilaku keagamaan seperti yang dijelaskan diatas yaitu seluruh aktifitas anggota tubuh manusia yang berdasarkan syariat Islam atau ibadah dalam arti luas baik yang berbentuk horizontal antara sesama makhluk, maka bentukbentuk perilaku keagamaan di sini bermacam-macam dan luas. Di dalam skripsi ini secara umum hanya akan dibahas tiga bentuk perilaku keagamaan yang dapat dirumuskan sebagai berikut: pertama, disiplin menjalankan perintah shalat. Bagi santri shalat merupakan bentuk pengabdian manusia dengan tuhannya yang harus dikerjakan oleh umat Islam dimanapun dan dalam kondisi apapun. Yang dimulai dari niat dengan takbiratul ihram dan diakhiri dengan salam. Orang Islam yang taat yaitu orang Islam yang mengerjakan shalat dengan hati gembira, senang, tidak merasa terpaksa, dan bukan karena malu pada sesama.

Sebagai salah satu dari rukun islam, solat merupakan tonggak segala macam ibadah. Oleh karena itu shalat dilambangkan sebagai tiang agama artinya tegak dan tidaknya agama itu akan tercermin dari ada tidaknya orang yang melakukan shalat. Dalam hal ini shalat merupakan ciri penting dari orang yang bertaqwa. Dalam kehidupan sehari-hari, apabila shalat dikerjakan dengan rajin dan penuh kekhusukan maka akan menuntun ke arah kebenaran perilaku dan sekaligus akan mampu menjauhkan diri dari hal-hal yang buruk. Dengan demikian, orang yang telah mampu 
mengerjakan shalat dengan kontinyu dengan baik dan benar serta penuh kekhusukan, maka merekalah orang-orang yang akan mendapatkan kebahagiaan, seperti Firman Allah:

Sesungguhnya beruntunglah orang-orang yang beriman, (yaitu) orang-orang yang khusyu' dalam sembahyangnya, (QS. Al Mukminun 1-2).49

Maksud disiplin ialah menjalan perintah shalat adalah ketaatan, kepatuhan, keteraturan seseorang di dalam menunaikan ibadah shalat wajib yang terdiri dari lima waktu sehari semalam lengkap dengan segala syarat serta rukun-rukunnya (Rifai'i, 1992, hal. 74).

Kedua, Jujur dan benar. Jujur adalah "memberitahukan, memutuskan sesuatu dengan sebenarnya". Jujur termasuk golongan akhlak mahmudah atau akhlak yang terpuji. Sedangkan benar artinya sesuatu yang sesuai dengan kenyataan yang sesungguhnya dan tidak hanya perkataan tetapi juga perbuatan (Humaidi, 1980, hal. 140). Kebenaran atau kejujuran sendiri merupakan sendi yang terpenting bagi berdiri tegaknya masyarakat. Tanpa kebenaran akan hancurlah masyarakat sebab hanya dengan kebenaran maka dapat tercipta adanya saling pengertian dan kepercayaan. Maka Islam menganjurkan bahkan menekankan agar unsur kejujuran ditanamkan kepada anakanak sejak kecil agar mereka terbiasa melakukan kejujuran. Kita tidak akan merasa tentram bila melakukan kebohongan dengan demikian kita akan selalu dapat mengendalikan diri dari ketidakjujuran sehingga orang lain akan merasa senang kepada kita. Sebagaimana firman allah swt:

Hai orang-orang yang beriman bertakwalah kepada Allah, dan hendaklah kamu bersama orang-orang yang benar.52

Ketiga, Disiplin terhadap peraturan kampus. Disiplin adalah kondisi yang tercipta dan terbentuk melalui proses dari serangkaian perilaku yang menunjukkan nilai-nilai kepatuhan, ketaatan, kesetian, keteraturan dan ketertiban (Djojonegoro, 1998, Hal. 20). Maksud disiplin dalam hal ini adalah ketaatan, kepatuhuan serta sikap tanggung jawab santri terhadap peraturan-peraturan yang berkenaan dengan pondok pesantren maupun peraturan yang ditentukan diri sendiri yang dengan hal itu akan dapat menjadikan adanya perubahan pada seorang santri. 


\section{Kegunaan Media sosial Bagi Kehidupan Santri di Pondok Pesantren}

Remaja dan media sosial merupakan dua kata yang tidak bisa dipisahkan, selalu berkaitan dan erat antara satu sama lain. Ketika dunia teknologi informasi dan media komunikasi semakin berkembang, media sosial muncul sebagai trendsetter disemua kalangan, terutama remaja. Sampai-sampai orang nomor satu di negeri ini pun tidak mau ketinggalan untuk memiliki akun facebook dan twitter sebagai bentuk media komunikasinya.

Facebook, What App, BBM, Line, Instagram salah satu media sosial yang sedang diganderungi remaja sekarang. Lekatnya remaja dengan media sosial menjadikan remaja memiliki dunia baru yaitu dunia maya. Bahkan terkesan dunia yang sesungguhnya adalah dunia yang ada pada media sosial. Media sosial dengan mudah mengubah pola dan tingkah laku serta kehidupan remaja. Kepribadian remaja yang masih labil begitu rentan serta dengan mudah dipengaruhi. Pencarian jadi diri yang terkadang salah tafsir membuat remaja berbuat sesuka hatinya tanpa mempertimbangkan nilai-nilai agama dan sosial. Tidak jarang remaja sering terjebak dalam sebuah pergaulan negatif, baik untuk dirinya, keluarga, lingkungan maupun orang lain.

Secara sadar bahwa santri yang ada di pondok pesanten Nurul Huda Kajen juga mengenal dengan adanya media sosial. Akan tetapi ada waktu tetentu saat memanfaatkan media tersebut. Ustad Shofwan menjelaskan bahwa semua santri boleh memanfaatkan media sosial dengan syarat tidak mengganggu belajar di sekolah dan ngaji di pondok. Kebanyakan santri mengejakan tugas di warnet dekat pondok pesantren. Terkadang disela-sela mengejakan tugas, santri juga membuka FB berbincang dengan teman ataupun kerabatnya. Bukan berarti di pondok anak hanya ditekankan untuk ngaji saja. Meskipun dilingkungan pondok satri tidak boleh membawa Hp.

\section{Analisis Sisi Positif Pada Media sosial Pada Remaja di Pondok Pesantren}

Remaja zaman sekarang tidak ada bedanya antara sekolah umum maupun agama. Akan tetapi setelah peneliti amati anak yang berasal dari madrasah, dari 
keluarga agamis maupun dari pondok pesantren masih memiliki nilai-nilai islami. Pelanggaran yang dilakukan anak remaja di pondok pesantren selama ini sangat biasa/tidak fatal. Misalnya, diberi tugas kelompok saat giliran ngaji. Santri tadi, membuat alasan agar bisa terbebas dari tugasnya. Hal yang perlu tidindak lanjuti ileh ustad/ustadah yaitu memberi ganjaran agar santri tersebut tidak mengulangi lagi.

Bahkan di pondok pesantren ada yang peraturannya sangat ketat, semua itu demi menyelamatkan diri para santri. Santri yang memiliki nilai-nilai agama, sangat jarang terjerumus ke dalam dunia negatif terutama kumpulan yang berdampak kerugian. Selain itu, dengan adanya dunia maya seperti media sosial sangat membantu para santri untuk lebih maju mengenalnya.Disamping itu, masyarakat mengapresiasi kepada Kementerian Komunikasi dan Informasi memang sudah berupaya keras untuk memblokir situs-situs porno. Kebebasan pada internet dan media sosial, menjadikan tidak ada filter bagi para penggunnya. Tanpa disadari banyak aktifitas kejahatan yang diawali dari media sosial, atau lebih dikenal dengan cyber crime, tindak kriminal pada dunia maya.

\section{Simpulan}

Hasil yang dapat dikemukakan pada artikel ini ialah bahwa secara fungsional media sosial dapat membantu para santri remaja untuk menjalin hubungan silaturahmi dan juga sebagai media untuk mencari pengetahuan baru, tetapi pada wilayah berbeda media sosial juga menjadi boomerang bagi santri remaja sebagai alat yang dapat menimbulkan sikap amoral. Meskipun demikian, pesantren tidak harus dijauhkan dari media karena kebutuhan zaman yang dapat mengantarkan santri mengenal dunia. 


\section{Referensi}

Amin, A. (1983). Etika Alih Bahasa K.H. Ahmad Ma'ruf. Jakarta: Bulan Bintang.

Ansyori, H. (1999). Dasar-Dasar Ilmu Jiwa Agama. Surabaya: Usaha Putera.

Atkinson, R. L. (n.d.). Pengantar Psikologi. Jakarta: PT Remaja Rosdakarya.

Azwar, S. (2010). Metode Penelitian. Yogyakarta: Pustaka Pelajar.

Barker, C. (2005). Cultural Studies Teori dan Praktek. Yogyakarta: Kreasi Wacana.

Djojonegoro, I. W. (1998). Pedoman Pelaksanaan Disiplin Nasional dan Tata Tertib Sekolah. Jakarta: Murni Daya.

Drajat, Z. (1970). Ilmu Jiwa Agama. Jakarta: Bulan Bintang.

H.M, A. (1997). Psikologi Dakwah. Jakarta: Bulan Bintang.

Hakim, A. (1979). Perbandingan Agama: Pandangan Islam Mengenai Kepercayaan: Majusi-Shabiah-Yahudi, Kristen-Hindu Dan Budha. Bandung: Diponegoro.

Halder, D. (2011). Information Technology Act and Cyber Terrorism: Critical Review. India: : Publications Division, Manonmaniam Sundaranar University.

Holmes, D. (2012). Komunikasi Media, Teknologi, dan Masyarakat. Yogyakarta: Pustaka Pelajar.

Humaidi. (1980). Tata Pengarsa Akhlak Yang Mulia. Surabaya: Guna Ilmu.

Jauhari, M. A. (2006). Perilaku Sosial Santri Pondok Pesantren Al-Ishlah Bandar Kidul Mojoroto Kota Kediri Setelah Mengikuti Pengajian Kitab Al-Hikam. Jurnal Spiritualita, 1(1), 1-18.

Kebudayaan, D. P. dan. (1989). Kamus Besar Bahasa Indonesia. Jakarta: Balai Pustaka.

Nasional, D. P. (2008). Kamus Besar Bahasa Indonesia. Jakarta: Gramedia Pustaka Utama.

Nasrullah, R. (2015). Media Sosial : Perspektif Komunikasi, Budaya dan Sosioteknologi. Jakarta: Simbiosa Rekatama Media.

Nugroho, W. (2016). Peran Pondok Pesantren dalam Pembinaan Keberagamaan Remaja. Jurnal Kajian Kependidikan Islam, 8(1), 89-116. https://doi.org/10.18326/mudarrisa.v8i1.89-116

Rifai'i, M. (1992). Akhlak Seorang Muslim. Semarang: Wicaksana. 
Rivers, W. L. (2012). Media Massa dan Masyarakat Modern. Jakarta: Kencana Prenadamedia Grup.

Roberston, R. (1993). Agama: dalam Analisa dan Interpretasi Sosiologis. Jakarta: Gramedia Pustaka Utama.

Saputra, E. (2016). Dampak Sosial Media terhadap Sikap melalui Pendidikan Agama Islam. Jurnal SOSISO-E-KONS, 8(2), 160-168.

Severin, W. J., \& Tankard, J. W. (2011). Teori Komunikasi Sejarah, Metode, dan Terapan Di Dalam Media Massa. Jakarta: Kencana Prenadamedia Grup.

Suroso, D. A. F. N. (2004). Psikologi Agama: Solusi Islam Atas Problem-Problem Psikologi. Yogyakarta: Pustaka Pelajar.

Vivian, J. (2008). Teori Komunikasi Massa. Jakarta: Kencana Prenadamedia Grup.

W.A, G. (1991). Psikologi Sosial. Bandung: Erkam Publications. 
Halaman ini bukan sengaja untuk dikosongkan 